\title{
Designation of lectotypes for certain species and subspecies of unilocular Nodosariida and Buliminida (Foraminifera), Part 1 - Those housed in the British Museum (Natural History)
}

\author{
ROBERT WYNN JONES \\ Robertson Research International Ltd., Ty'n-y-Coed, Llanrhos, Llandudno, Gwynedd LL30 1SA, U.K.
}

\begin{abstract}
Lectotypes are herein designated for 20 lagenoid species and subspecies housed in the British Museum (Natural History) and paralectotypes are also selected for eight of these. The original figures of all are reproduced, and those of two are supplemented by means of light photomicrographs. A brief discussion as to the whereabouts of the collections of Rymer Jones (1874) and Chaster (1892) is appended.
\end{abstract}

\section{INTRODUCTION}

It often becomes necessary, in the interest of maintaining stability of nomenclature, to designate lectotypes for those species for which the original author did not propose holotypes and paratypes (this was accepted practice until comparatively recently).

The purpose of the present paper is to designate lectotypes for 20 lagenoid species and subspecies and select paralectotypes for eight of these, in order to place on a sounder taxonomic basis some of the forms discussed by the author in his recent paper (in press) on a revised classification on the unilocular Nodosariida and Buliminida (scheduled for publication in May 1984).

It was the author's original intention to designate lectotypes (where appropriate) for all of the species mentioned therein, but, as they are housed in a number of institutions, this is considered beyond the scope of a single paper. Part 2 (in prep.) will deal with those deposited in the National Museum of Ireland, Dublin. The present work deals only with those in the British Museum (Natural History). These types are listed alphabetically in Table 1 and illustrated on Plates 1 and 2 , mostly from the original figures.

\section{NOTES ON SOME IMPORTANT BRITISH COLLECTIONS}

Adams et al. (1980) state that "The collections on which the first 4 publications on British foraminifera were based (Walker \& Boys, 1784; Walker \& Jacob, 1798; Montagu, 1803 and 1808) must be presumed lost."

Regrettably, the same conclusion is reached herein with regard to the collection of Rymer Jones, 1874 and at least that part of the collection of Chaster, 1892 containing most of the new species and varieties of "Lagenae" (see Appendices).

Hence, this paper focuses on specimens in the collections of Williamson (or at least the extant part thereof),
Parker \& Jones, Brady, Millett, Sidebottom, HeronAllen \& Earland and Earland. For further information regarding these collections (their histories etc.), the reader is referred to Adams et al. $(1980$, p. 2).

\section{ACKNOWLEDGEMENTS}

The author is indebted to the staff of the Department of Palaeontology, British Museum (Natural History), in particular to Mr. R. L. Hodgkinson and Dr. J.E. Whittaker, for their assistance and advice.

Thanks are also due to J.H. Fiddian-Green, Executive Secretary, and Gina Douglas, Librarian, of the Linnaean Society of London, to Miss Patricia Methven, Archivist, of King's College, London, and to Dr. P. Graham Oliver of the Department of Invertebrate Zoology, National Museum of Wales, Cardiff, for their helpful co-operation in the fruitless search for the Rymer Jones and Chaster collections of "Lagenae".

Mrs. V.C. Stirling typed the manuscript.

Dr. J. R. Haynes, of the University College of Wales, Aberystwyth, critically reviewed the manuscript.

Robertson Research International Ltd., undertook the photographic work, and the whole paper was funded by Robertson Research Co. project number $834 / 71243$, the receipt of which is gratefully acknowledged. 
Table 1. Alphabetical List of Taxa and Status of Specimens

\begin{tabular}{|c|c|c|c|}
\hline TAXON & Original Pl./fig. nos. & $\begin{array}{l}\text { B.M.(N.H.) } \\
\text { reg. no. }\end{array}$ & STATUS $\begin{array}{c}\text { (herein) } \\
\text { (designated) }\end{array}$ \\
\hline $\begin{array}{l}\text { Entosolenia squamosa (Montagu) } \\
\text { var. hexagona Williamson, } 1848\end{array}$ & $\begin{array}{l}\text { Figured specimen } \\
\text { not recognised }\end{array}$ & $\begin{array}{l}96: 8: \\
13: 67 *_{1}\end{array}$ & LECTOTYPE \\
\hline Lagena alveolata Brady, 1884. & $\begin{array}{l}\text { Pl. } 60 \text {, fig. } 30 . \\
\text { Pl. } 60 \text {, fig. } 32, \\
\text { and unfigured. }\end{array}$ & $\begin{array}{l}\text { ZF4311 } \\
\text { ZF1612 }\end{array}$ & $\begin{array}{l}\text { LECTOTYPE } \\
\text { PARALECTOTYPES }\end{array}$ \\
\hline $\begin{array}{l}\text { Lagena alveolata Brady var. } \\
\text { separans Sidebottom, } 1912\end{array}$ & $\begin{array}{l}\text { Pl. 21, fig. } 5 . \\
\text { Unfigured. }\end{array}$ & $\begin{array}{l}\text { ZF4306 } \\
\text { ZF4307-8 }\end{array}$ & $\begin{array}{l}\text { LECTOTYPE } \\
\text { PARALECTOTYPES }\end{array}$ \\
\hline $\begin{array}{l}\text { Lagena apiculata (Reuss) var. } \\
\text { punctulata Sidebottom, } 1912 .\end{array}$ & $\begin{array}{l}\text { Pl. 14, fig. } 21 . \\
\text { Pl. 14, fig. } 23 \text {. }\end{array}$ & $\begin{array}{l}\text { ZF4309 } \\
\text { ZF4310 }\end{array}$ & $\begin{array}{l}\text { LECTOTYPE } \\
\text { PARALECTOTYPE }\end{array}$ \\
\hline $\begin{array}{l}\text { Lagena auriculata Brady var. } \\
\text { costata Brady, } 1881 .\end{array}$ & Pl. 60, fig. 38 (1884). & ZF4312 & LECTOTYPE \\
\hline $\begin{array}{l}\text { Lagena bisulcata Heron-Allen \& } \\
\text { Earland, } 1932 .\end{array}$ & $\begin{array}{l}\text { Pl. 11, fig. } 29 . \\
\text { Pl. 11, figs. 30-32. }\end{array}$ & $\begin{array}{l}\text { ZF4313 } \\
\text { ZF3322 }\end{array}$ & $\begin{array}{l}\text { LECTOTYPE } \\
\text { Figured and other } \\
\text { PARALECTOTYPES }\end{array}$ \\
\hline $\begin{array}{l}\text { Lagena clavata (d'Orbigny) var. } \\
\text { setigera Millett, } 1901 .\end{array}$ & $\begin{array}{l}\text { Figured specimen } \\
\text { not recognised. } *_{2}\end{array}$ & $\begin{array}{l}1955: \\
11: 1: \\
1375\end{array}$ & LECTOTYPE \\
\hline Lagena cymbaeformis Millett, 1895. & Pl. ?* ${ }_{3}$, fig. 3 . & P51662 & LECTOTYPE \\
\hline $\begin{array}{l}\text { Lagena cymbula Heron-Allen \& } \\
\text { Earland, } 1913 .\end{array}$ & $\begin{array}{l}\text { Figured specimen } \\
\text { not recognised. }\end{array}$ & ZF4314 & LECTOTYPE $_{4}$ \\
\hline Lagena fimbriata Brady, 1881. & Pl. 60, fig. 26 (1884). & ZF1654 & LECTOTYPE \\
\hline $\begin{array}{l}\text { Lagena foveolata Reuss (?) var. } \\
\text { paradoxa Sidebottom, } 1912 .\end{array}$ & Pl. 16, fig. 22. & ZF4319 & LECTOTYPE \\
\hline $\begin{array}{l}\text { Lagena globosa (Montagu) var. } \\
\text { setosa Earland, } 1934 .\end{array}$ & Pl. 6, fig. 52 . & ZF3338 & LECTOTYPE \\
\hline Lagena gracilis Williamson, 1848. & $\begin{array}{l}\text { Figured specimen } \\
\text { not recognised. }\end{array}$ & $\begin{array}{l}96: 8: \\
13: 53 *_{5}\end{array}$ & LECTOTYPE \\
\hline $\begin{array}{l}\text { Lagena marginata (Montagu) (sic.) } \\
\text { var. spinifera Earland, } 1934 .\end{array}$ & Pl. 7, figs. 3-4. & ZF3358 & $\begin{array}{l}\text { LECTOTYPE and } \\
\text { unregistered } \\
\text { figured } \\
\text { PARALECTOTYPE }\end{array}$ \\
\hline $\begin{array}{l}\text { Lagena quadrilaterata Earland var. } \\
\text { striatula Earland, } 1934\end{array}$ & Pl. 7, fig. 9. & ZF3368 & LECTOTYPE \\
\hline
\end{tabular}


Table 1. continued.

\begin{tabular}{|c|c|c|c|}
\hline TAXON & Original Pl./fig. nos. & $\begin{array}{l}\text { B.M.(N.H.) } \\
\text { reg. no. }\end{array}$ & STATUS $_{\text {(designated) }}^{\text {(herein) }}$ \\
\hline
\end{tabular}

$\begin{array}{llll}\text { Lagena reniformis Sidebottom, 1913. Pl. 18, fig. 14. } & \text { ZF4318 } & \begin{array}{l}\text { LECTOTYPE } \\ \text { and unfigured } \\ \text { PARALECTOTYPE }\end{array}\end{array}$

Lagena stelligera Brady, 1881. $\quad$ Pl. 57, fig. 35 (1884). $\quad$ ZF1771 $\quad$ LECTOTYPE

Lagena stelligera Brady var. nelsoni Heron-Allen \& Earland, 1922

Pl. 5, figs. 20-22.
1922:

10:26:

73

ZF4316

ZF4317
LECTO'TYPE and two figured PARALECTOTYPES

Lagena sulcata (Walker \& Jacob) var. striatopunctata Parker \& Jones, 1865.

Pl. 13, fig. 26.

PI. 13, fig. 27.

Figured specimen

Lagena unguis Heron-Allen \&

Earland, 1913.

not recognised.

LECTOTYPE

PARALECTOTYPE

$*_{1}$ Strew slide labelled Entosolenia, ringed specimen (presumed syntypic) designated lectotype.

$*_{2}$ fide Whittaker \& Hodgkinson, 1979. Lectotype indicated on slide.

$*_{3}$ Plate not numbered on original.

$*_{4}$ Fragility of test precludes photography of lectotype.

$*_{5}$ Strew slide labelled Lagena gracilis, arrowed specimen designated lectotype.

\section{REFERENCES}

Adams, C. G., Harrison, C. A. \& Hodgkinson, R. L. 1980. Some primary type specimens of foraminifera in the British Museum (Natural History). Micropalaeontology, 26(1), $1-16$.

Brady, H.B. 1881. Notes on some of the reticularian Rhizopoda of the Challenger Expedition: Part 3, 1-Classification, 2 - Further notes on new species, 3 - Note on Biloculina mud. Quart. Journ. Micro. Sci., new ser., 21 , 31-71.

Brady, H. B. 1884. Report on the Foraminifera dredged by H.M.S. Challenger during the years 1873-76. Rep. scient. Results Voy. Challenger, London, 9, 1-814, 115 pls.

Chaster, G.W. 1892. Report on the Foraminifera of the Southport District. Rep. Southport Soc. nat. Sci., 4, 54-72, 1 pl.

Earland, A. 1934. Foraminifera, Part III. The Falklands Sector of the Antarctic (excluding South Georgia). Discovery Repts., 10, 1-208, 10 pls.

Heron-Allen, E. \& Earland, A. 1913. Clare Island Survey. Foraminifera. Proc. R. Ir. Acad., Dublin, 31 (64), 1-188, 13 pls.

Heron-Allen, E. \& Earland, A. 1922. Profozoa. Part 2 Foraminifera. Nat. Hist. Rep. Br. Antarct. 'Terra Nova' Exped., London (Zool.), 6, 25-268, 8 pls.

Heron-Allen, E. \& Earland, A. 1932. Foraminifera, Part I. The ice-free area of the Falkland Islands and adjacent seas. Discovery Repts., 4, 291-460, 12 pls.

Jones, F.W. O. Rymer. 1874. On some Recent forms of Lagenae from deep sea soundings in the Java Seas. Trans. Linn. Soc. Lond., 30, 45-69, 1 pl.
Jones, R.W. 1984 (in press). A revised classification of the Unilocular Nodosariida and Buliminida (Foraminifer). Rev. Esp. Micropal., 16.

Millett, F. W. 1895. The Foraminifera of the Pliocene beds of St. Erth. Trans. R. Geol. Soc. Corn., Penzance, 11, 655-661. $1 \mathrm{pl}$.

Millett, F. W. 1901. Report on the Recent Foraminifera of the Malay Archipelago collected by Mr. A. Durrand, Part XI. Jl. R. microsc. Soc., London, 1901, 485-497, 1 pl.

Montagu, G. 1803. Testacea Britannica, or natural history of British shells, marine, land, and freshwater, including the most minute. 606 pps., 16 pls. J. S. Hollis, Romsey, England.

Montagu, G. 1808. A supplement to the Testacea Britannica. 183 pps., 30 pls. S. Woolmer, Exeter.

Parker, W. R. \& Jones, T. R. 1865. On some Foraminifera from the North Atlantic and Arctic Oceans, including Davis Straits and Baffin's Bay. Phil. Trans. R. Soc., London, 155, $325-441,8$ pls.

Sidebottom, H. 1912. Lagenae of the South-West Pacific Ocean. J. Quekett microsc. Club., London, 11, 375-434, 8 pls.

Sidebottom, H. 1913. Lagenae of the South-West Pacific Ocean (Supplementary Paper). J. Quekett microsc. Club., London, 12, 161-210, 4 pls.

Walker, G. \& Boys, W. 1784. Testacea minuta rariora ruperrime detecta in arena littoris Sandvicensis a Gnl. Boys, arm S.A.S. Multa addidit, et omnium figuras opemicroscopii ampliatas accurate delineavit Geo. Walker. 25 pps., 3 pls. J. March, London. 
Walker, G. \& Jacob, W. 1798. In Adams, G. (Ed.) Essays on the microscope, containing a practical description of the most improved microscopes; a general history of Insects. A description of 383 animalcula etc., 2nd edition with considerable additions and improvements by F. Kanmacher. 712 pps., 32 pls. Dillon \& Keating, London.

Whittaker, J. E. \& Hodgkinson, R. L. 1979. Foraminifera of the Togopi Formation, eastern Sabah, Malaysia. Bull. Br. Mus. Nat. Hist., London (Geol.), 31(1), 1-120, 10 pls.

Williamson, W. C. 1848 . On the Recent British species of the genus Lagena. Ann. Mag. nat. Hist., London, ser. 2, 1, 1-20, 2 pls.

\section{APPENDIX 1: WHEREABOUTS OF THE RYMER JONES COLLECTION}

F. W. O. Rymer Jones' paper on the Lagenae from deep sea soundings in the Java Seas was evidently intended by him as the first part of a monographic treatment of the foraminiferal faunas of that region, but it seems that it was the only part that he completed, for its publication in 1874 appears to have coincided approximately with the time of his early death. Indeed, evidence from the text (p. 49) indicates that the text and figures were produced ". . . while in a recumbent position on an invalid's couch. ...."

The paper was communicated to the Linnaean Society of London in 1872 through the then secretary, H.J. Stainton (as was customary at the time). The death of Rymer Jones is alluded to in a letter from Stainton to the succeeding secretary, written in early 1876 , urging that reprints of the paper be sent to the young man's parents without delay.
F. W. O. Rymer Jones' father (T. Rymer Jones) was himself an eminent zoologist, author of a paper on Foraminifera in "The Intellectual Observer", Member of the Royal College of Surgeons, sometime physiology lecturer and Professor of Zoology and Comparative Anatomy at King's College, London from 1836 until his early retirement in 1874 . He died in 1880 . It seems that this influential man had in his possession at some time not only a copy of the paper but possibly also the actual Java Seas material, acquired from Lieutenant A. Ross of H.M.S. 'Serpent'. There is no tangible evidence as to what he did with the foraminiferal collection, although some correspondence suggests that he sold it (with various other teaching aids) to King's College on leaving. Unfortunately, it does not appear to be in the Stebbings Collection housed in that institution, and it is herein presumed lost.

\section{Explanation of Plate 1}

Figs. 1-3. Entosolenia squamosa (Montagu) var. hexagona Williamson, 1848 (fig. 1 after Williamson, $\times 108$; fig. 2 lectotype, $\times 128$; fig. 3 , close-up of lectotype, $\times 192$ ).

Figs. 4-5. Lagena alveolata Brady, 1884 (figs. after Brady, ×60). (Lectotype, fig. 4).

Figs. 6-7. Lagena alveolata Brady var. separans Sidebottom, 1912 (figs. after Sidebottom, $\times 75$ ). Lectotype.

Figs. 8-10. Lagena apiculata (Reuss) var. punctulata Sidebottom, 1912 (figs. after Sidebottom, $\times 50$ ). Lectotype, fig. 8; specimen shown in fig. 9 not recognised).

Figs. 11-12. Lagena auriculata Brady var. costata Brady, 1881 (figs. after Brady, 1884, × 60). Lectotype.

Figs. 13-16. Lagena bisulcata Heron-Allen \& Earland, 1932 (figs. after Heron-Allen \& Earland, $\times$ 55). (Lectotype, fig. 13).

Figs. 17-18. Lagena clavata (d'Orbigny) var. setigera Millett, 1901 (figs. after Millett, $\times 90$ ).

Figs. 19-21. Lagena cymbaeformis Millett, 1895 (figs. after Millett, $\times 135$ ). (Lectotype, fig. 21 ; specimen(s) shown in figs. 19, 20 not recognised).

Figs. 22-24. Lagena cymbula Heron-Allen \& Earland, 1913 (figs. after Heron-Allen \& Earland, $\times 200$ ). 

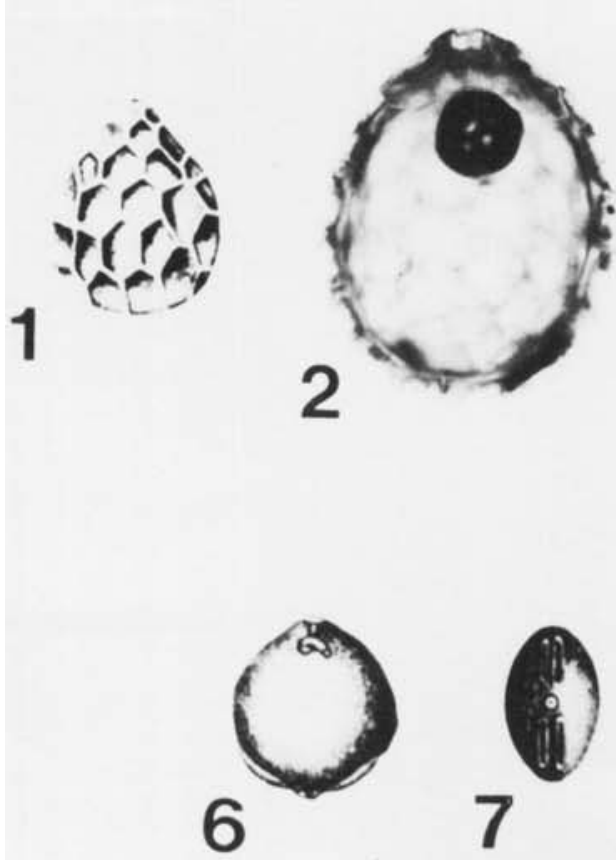

11
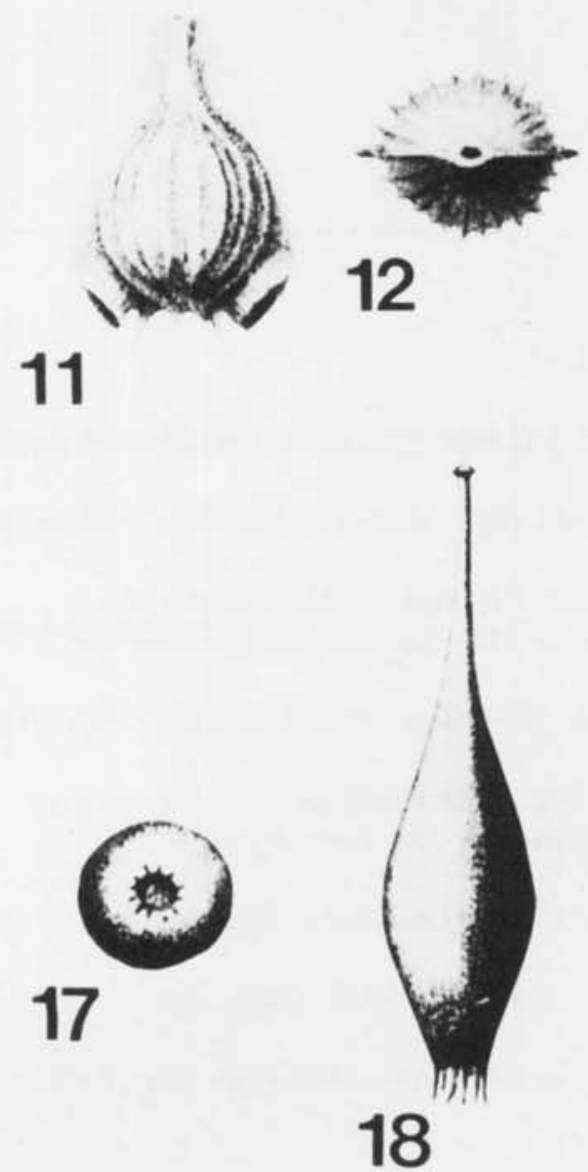
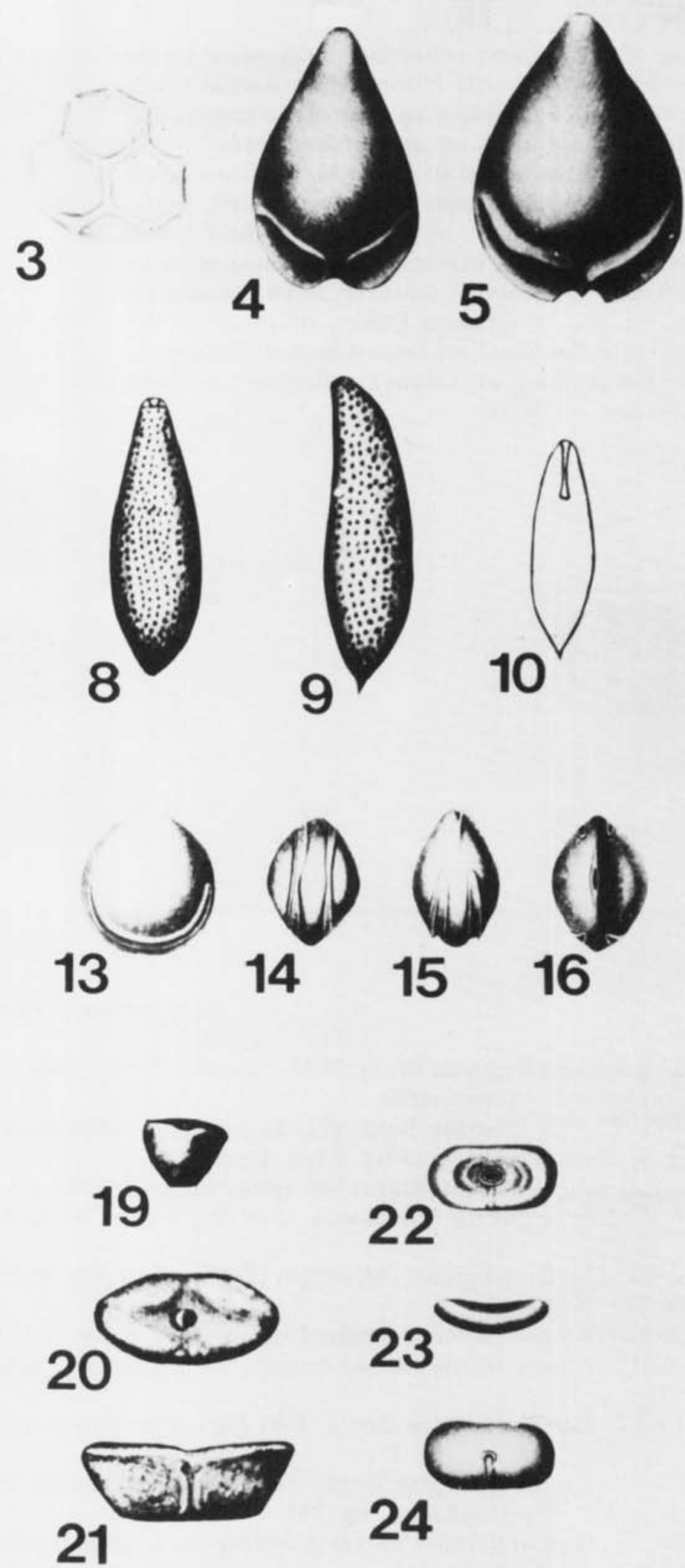


\section{APPENDIX 2: WHEREABOUTS OF THE CHASTER COLLECTION}

Some of the Chaster collection is deposited in the British Museum (Natural History) (see Adams et al., 1980 ) but that part containing most of the species and varieties of 'Lagenae' is not to be found there.

There exists, however, in the B.M. (N.H.) a letter from the National Museum of Wales, Cardiff, to the effect that, at one time, at least part of the Chaster Collection was residing in that institution (in an old shoe box!). This would appear, however, to be the case no longer, for Dr. P. Graham Oliver, of the N.M.W., informs the author that "the Department of Zoology ... has no foraminifera ex Chaster collection" (written communication, 1983).

\section{Explanation of Plate 2}

Figs. 1-3. Lagena fimbriata Brady, 1881 (figs. after Brady, 1884, $\times 60$ ). (Lectotype, fig. 1; specimen shown in figs. 2, 3 probably not conspecific).

Figs. 4-5. Lagena foveolata Reuss (?) var. paradoxa Sidebottom, 1912 (figs. after Sidebottom, $\times 75$ ). (Lectotype, fig. 4 ; specimen shown in fig. 5 not recognised).

Fig. 6. Lagena globosa (Montagu) var. setosa Earland, 1934 (fig. after Earland, $\times 50$ ). Lectotype.

Figs. 7-8. Lagena gracilis Williamson, 1848 (fig. 7 after Williamson, $\times 113$; fig. 8, lectotype, $\times 90$ ).

Figs. 9-10. Lagena marginata (Montagu) (sic) var. spinifera Earland, 1934 (figs. after Earland, $\times 70$ ). (Lectotype, fig. 9).

Fig. 11. Lagena quadrilaterata Earland var. striatula Earland, 1934 (fig. after Earland, $\times 75$ ). Lectotype.

Figs. 12-13. Lagena reniformis Sidebottom, 1913 (figs. after Sidebottom, $\times 75$ ). Lectotype.

Figs. 14-17. Lagena stelligera Brady, 1881 (figs. after Brady, 1884, × 75). (Lectotype, figs. 14, 16).

Figs. 18-20. Lagena stelligera Brady var. nelsoni Heron-Allen \& Earland, 1922 (figs. after Heron-Allen \& Earland, $\times 70$ ). (Lectotype, fig. 18).

Figs. 21-23. Lagena sulcata (Walker \& Jacob) var. striatopunctata Parker \& Jones, 1865 (figs. after Parker \& Jones, $\times 24)$. (Lectotype, fig. 21).

Figs. 24-26. Lagena unguis Heron-Allen \& Earland, 1913 (figs. after Heron-Allen \& Earland, $\times 120$ ). 

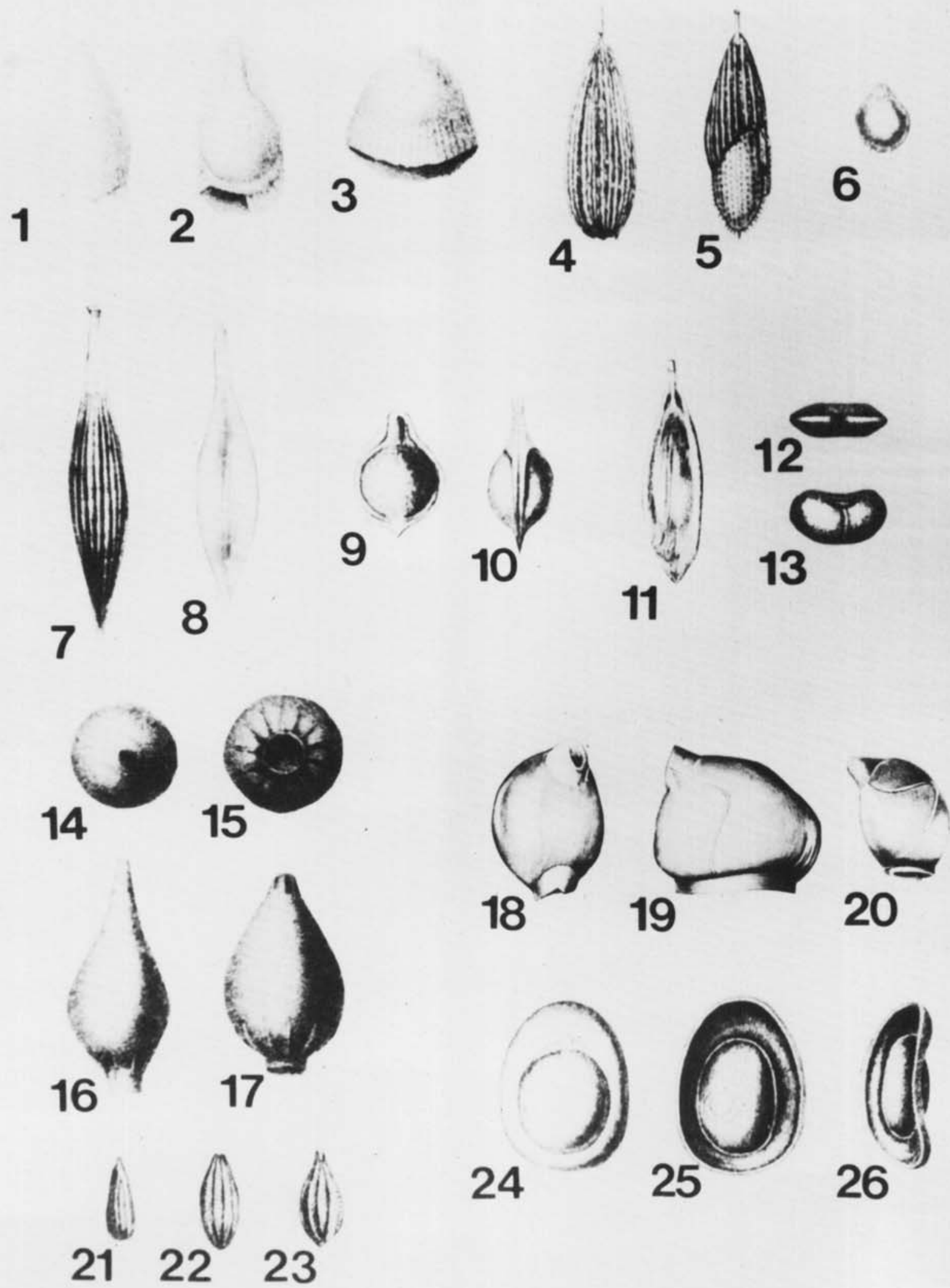

24
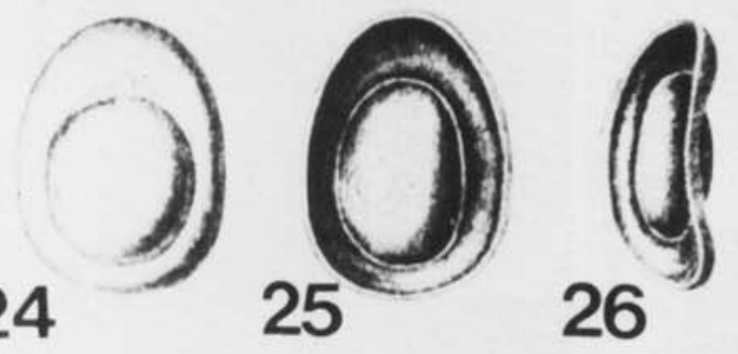